\title{
Foreign Direct Investment (FDI) in Bangladesh: Trends, Challenges and Recommendations
}

\author{
Abdin $\mathbf{M J}^{*}$ \\ Program Officer, Planning, Monitoring and Evaluation Wing, SME Foundation, Bangladesh
}

\begin{abstract}
During the liberation war in 1971 a nationalist weave emerged which gives Bangladeshis a spirit of freedom and dignity of independence but it also results on more reserved position in case of economic policy. Policy makers at that period used to see foreign companies access with a negative eyes. Foreign investments were discouraged as a result foreign direct investment (FDI) inflow in Bangladesh till 1980 is very insignificant. The growth of Bangladesh's FDI inflow was around US\$308-356 million for long fifteen years (1980-1995) which started with an amount of US $\$ 0.090$ million in 1972. Afterwards this concept has been changed into a reverse position and government start encouraging foreign direct investment from 1990s. A series of policy incentives, investment sovereignty has been offered to the FDI investors including tax holiday for several years, duty free facility for importing capital machinery, $100 \%$ foreign ownership, $100 \%$ profit repatriation facility, reinvestment of profit or dividend as FDI, multiple visa, work permit to foreign executives, permanent resident or even citizenship for investing a specific amount, Export Processing Zone (EPZ) facility, and easy hassle free exit facility. Potential sectors of can attract more FDI are power generation, infrastructure development, private port establishment, joint venture with deep sea port establishment under PPP, ship building, ICT sector, call center, education, healthcare, mining, gas extraction, agro processed product, electrical and electronics, light engineering, and fashion designing etc. After so many incentives offered by the government till now FDI Inflow into Bangladesh is not at a satisfactory level. During last few years fresh FDI investment in not taking place. From the statistics of last few years it is quite clear that, reinvestment of locally earned profit is the major amount of FDI into Bangladesh. Fresh FDI inflow is decreasing day by day. Government has to investigate the issue and undertake necessary measures to increase fresh FDI into Bangladesh.
\end{abstract}

Keywords: Foreign direct investment; FDI into Bangladesh; Investment climate in Bangladesh; Incentive available for FDI investors in Bangladesh

\section{JEL Codes: F21, F23, H11}

\section{Introduction}

Bangladesh is one of the N11 Countries [1]. It is considered as a land of opportunities because it is growing 6\%-7\% annual growth rate during last one and half decade without any major governmental incubation. Bangladesh has a very strong resilience power to progress with so many barriers and disasters. Shortage of electricity, infrastructural insufficiency, and political instability nothing has been stopped this around 6\% growth during last decade. Its industrial base do not get maturity in any sector, industrial specialization is also absent here. This growth is driven by the 60 lac small and medium enterprises (SMEs) along with micro and cottage enterprises located all over the country with concentration at divisional headquarters [2]. Most of the MSMEs are out of any government incentives, loan coverage and technical up gradation. If existing MSMEs could get governments technical, regulatory and financial support then they alone could bring a double digit (10\%) growth for the country. There are $177 \mathrm{SME}$ Clusters (natural industrial park) throughout the country [3]. All the clusters have potentials to grow further. But without technical up gradation current growth will not be sustain for long time.

The foreign direct investment (FDI) is considered as one of the major sources of employment generation, technology transfer, and managerial capacity building, and increasing market efficiency in any country.

Now come to the point that, why companies go for FDI investment? This is because global competition among the multinationals is rising tremendously. Factors of production e.g. land, labor, capital are becoming costlier in the developed world. As a result producing economy product by maintaining satisfactory quality is a major threat to the TNCs \& MNCs. Without a standard product in competitive price a company may not remain competitive around the world. For this reason global investors are searching for a more competitive location where factors of production are available at a competitive rate and market access of the products could be ensured. Relocation of the labor intensive industries towards the developing countries is the result of this tension of global investors.

On the other hand; export earnings, remittance and the foreign direct investment (FDI) are three major sources of revenue of a least developed country. Therefore governments are offering special packages to the foreign investors for attracting FDI. Developing countries are somehow in an advantageous position to attract FDI than the least developed countries (LDC). But some LDC has absolute advantage over the developing countries in comparison of land and labor cost. Adequate manpower supply, large local market and special packages from the government side remain them in the field.

Bangladesh is such an LDC with absolute advantage to attract FDI. Though beginning of our FDI attraction was not so good before 1980 s due to nationalization movement of government soon after the independence. A misconception was there that is allowing foreign direct investment means preserving foreign interest. Luckily that misconception was not lasting long and Bangladeshi policy makers understood that, government cannot run the economy and private

*Corresponding author: Abdin MJ, Program Officer, Planning, Monitoring and Evaluation Wing, SME Foundation, Bangladesh, Tel: +88-02-8142983 (Ext. 133); E-mail: mdjoynal@gmail.com

Received July 09, 2015; Accepted July 16, 2015; Published July 21, 2015

Citation: Abdin MJ (2015) Foreign Direct Investment (FDI) in Bangladesh: Trends, Challenges and Recommendations. Int J Econ Manag Sci 4: 276. doi:10.4172/21626359.1000276

Copyright: (C) 2015 Abdin MJ. This is an open-access article distributed under the terms of the Creative Commons Attribution License, which permits unrestricted use, distribution, and reproduction in any medium, provided the original author and source are credited. 
sector should take the lead. At the same time government started to allow joint venture investment from 1980s but somehow a discouraging tendency was there. As a result growth of Bangladesh's FDI inflow was around US\$ 308-356 million for long fifteen years (1980-1995) which started with an amount of US $\$ 0.090$ million in 1972. With Bangladesh government's opening up energy and telecom sectors in mid 90s FDI inflow raised dramatically. Others factors like establishing the Board of Investment (1989), easing capital control and bureaucratic red tapism were also contributed in rapid growth of FDI inflow from 1997 which was near about three times (US \$ 1,407 million) than that of previous year 1996 (US\$ 535 million). After implementing all prerequisites of free market economy, establishing EPZs, declaring a handsome amount of fiscal and non-fiscal incentives Bangladesh's performance in FDI attraction in recent year is not satisfactory. It is not growing as it should be, question may be raised that, Bangladesh earned US \$ 1.09 billion FDI in 2009 it is $63 \%$ more than 2008 [4]. This flow raised into USD 1.13 billion, 1.29 billion in 2011 and 2012 respectively [5]. If we would like to compare Bangladesh's performance with other South Asian Countries like India earned US $\$ 28$ billion FDI inflow, Pakistan earned US $\$ 8.5$ billion FDI inflow in 2012 [6].

\section{Problem Statement and Research Questions}

Bangladesh is a least developed country (LDC) located at South Asia, About $31.5 \%$ of its population are living below the poverty line [7]. There are 56.7 million workable population in Bangladesh with 2 million unemployed population [8]. Another 1.8 million educated workforce is entering into the job market per year [9]. Providing employment opportunity to such a huge population is quite difficult task for the government as well as local private sector. Therefore government is welcoming foreign investment into Bangladesh to facilitate employment opportunity, foster economic growth and poverty alleviation. Government is offering many fiscal and non-fiscal incentives to the FDI investors. Factor of production like land, labor etc. are available at a competitive rate here. But rate of FDI investment into Bangladesh is not getting momentum. We would like to analyze how much FDI Bangladesh do received since its independence? What are the factors hindering FDI flow into Bangladesh? How Bangladesh could increase FDI inflow? To facilitate employment generation, increase GDP growth rate, technology transfer and finally poverty alleviation.

\section{Objective of the Study}

The government of Bangladesh took many initiatives to attract FDI into the country through international road show, special tax holiday, $100 \%$ repatriation of dividend and invested capital, resident ship, citizenship and many more lucrative offers are available for the foreign direct investors in Bangladesh. But response is not up to the mark. We would like to study about what more can be done to attract FDI in Bangladesh? What is the present trend? Which are the sector having potentials to attract FDI? What are the challenges and how can be addressed to overcome the challenges? Who are the countries investing in Bangladesh? What are the sector attracting more FDI? What are the new sectors can be promoted to attract FDI? How government can strengthen FDI attraction campaign to get optimum result?

\section{Methodology of the Study}

This is mainly a secondary information based study. We would like to analyze and compare relationship with FDI and export growth, per capita earnings etc. to identify impact of FDI on Bangladesh economy. Sector wise FDI trend and potential sector were analyzed based on previous record and current export earnings as well as global trend of this sector. A focus group discussion (FGD) was conducted to identify challenges toward FDI inflow in Bangladesh. Few key informant interviews (KII) were taken to enrich this study with specialized views of experts.

\section{Scope of the study}

We would like to know about the monetary and non-monetary incentives Bangladesh is offering to FDI investors? Analyze FDI flow into Bangladesh during last ten years. Which sectors are getting more attention of the FDI investors? What are the potential sectors for investment in Bangladesh? What government could do more to attract FDI into Bangladesh?

\section{Limitations}

This research is mainly result of and FGD and few KII along with review of available secondary literatures. Respondents are mainly academicians, businessmen, and trade body professionals. If higher government officials from the respective offices and foreign investors wants to invest into Bangladesh could cover then the research could be more useful.

\section{Literature Review}

Foreign Direct Investment is the category of international investment that reflects the objective of a resident entity in one economy obtaining a lasting interest in an enterprise resident in another economy [10-13]. A foreign direct investor is an individual, an incorporated or unincorporated public or private enterprise, a government, a group of related individuals, or a group of related incorporated and/or unincorporated enterprises which has a direct investment in an enterprise that is, a subsidiary, associate or branch operating in a country other than the country or countries of residence of the foreign direct investor or investors.

Companies go for FDI mainly from three motives i.e. to expand sales mean to access into a larger market, to acquire resources means to buy/hire more resources and to minimize risk. Other reasons of companies doing FDI are flexible labor market, low cost labor; low corporate tax, availability of skilled workers, availability of duty free market access in developed countries etc. are prominent. Extreme competition in international market pushed thinking for relocation of labor-intensive industries into cheaper labor markets.

On the other hand, FDI increases government revenue earnings via corporate tax, income tax, and VAT, employment generation, technology transfer, increasing GDP growth, provide funds from outside the country to develop new sectors, increase per capita income by employing local workforce, enact corporate culture and promote CSR activities in host country. FDI has a positive impact on balance of payment; reduce import by producing import substitute products and save foreign exchange. Finally FDI helps to alleviate poverty and foster economic development of host country.

FDI bears risk of political factors mainly; with the change of government fundamental economic policies like fiscal policy, monetary policy, as well as sometime sovereignty risks also involved. Similarly; FDI are giant MNCs may create distortion in level playing field of competition, local small companies may face successive competition and through out of market. So, a threat to local investors is there. Secondly FDI companies may involve in over invoicing, at a time repatriation may be cause of deeper economic crisis and higher 
Citation: Abdin MJ (2015) Foreign Direct Investment (FDI) in Bangladesh: Trends, Challenges and Recommendations. Int J Econ Manag Sci 4: 276. doi:10.4172/21626359.1000276

Page 3 of 5

unemployment rate as well as projected technology transfer may not occurred.

\section{Business Environment of Bangladesh for a Foreign Investor}

Bangladesh is one of the promising economies with a large domestic market, availability of labor with competitive price, low utility charges, two Seaports and a potential Deep Seaport facility, long-term tax holiday, $100 \%$ repatriation facility, and easy access to largest regional market like India and China.

\section{Facilities and Incentives for a foreign investor}

1. Tax exemption on royalties, technical knowhow and technical assistance fees and facilities for their repatriation

2. Tax exemption on interests on foreign loans

3. Tax exemptions on capital gains from transfer of shares by the investing company

4. Remittances of up to $50 \%$ of salaries of the foreigners employed in Bangladesh and facilities for repatriation of their savings and retirement benefits at the time of their return

5. No restrictions on issuance of work permits to project related foreign nationals and employees

6. Facilities for repatriation of invested capital, profits and dividends

7. Provision of transfer of shares held by foreign shareholders to local investors

8. Reinvestment of remittable dividends would be treated as new investment

9. Level playing field: foreign owned companies duly registered in Bangladesh will be on the same footing as locally owned ones

\section{Fiscal incentives}

1. Corporate tax holiday of 5 to 7 years for selected sectors

2. Reduced tariff on import of raw materials capital machinery

3. Bonded warehousing

4. Accelerated depreciation on cost of machinery is admissible for new industrial undertaking $(50 \%$ in the first year of commercial production, $30 \%$ in the second year, and $20 \%$ in the third year)

5. Tax exemption on capital gains from the transfer of shares of public limited companies listed with a stock exchange

6. Reduced Corporate Tax for 5 to 7 years in lieu of tax holding and agricultural deprecation.

\section{Financial incentives for export oriented industries}

1. Cash incentives and export subsidies ranging from $5 \%$ to $20 \%$ granted on the FOB value of the selected products

2. $90 \%$ loans against letters of credit (by banks)

3. Permission for domestic market sales of up to $20 \%$ of exportoriented companies outside EPZ (relevant duties apply)

\section{Additional facilities/incentives}

1. $100 \%$ foreign equity allowed.
2. Unrestricted exit policy

3. Remittance of royalty, technical know-how and technical assistance fees

4. Full repatriation facilities of dividends and capital at exit

5. Citizenship by investing a minimum of US\$ $\$, 00,000$

6. Permanent resident permits on investing US $\$ 75,000$

7. An investor can wind up investment either through a decision of the AGM or EGM. He or she can repatriate the sales proceeds after securing proper authorization from the Central Bank

\section{Trend of FDI inflow into Bangladesh}

Net foreign investment Bangladesh received during last few years: From the Table 1 it is clear that, net FDI inflow into Bangladesh was not stable during last decade.

\section{Sectors received maximum FDI}

Foreign Investment has come to Bangladesh in the following sectors as shown in Table 2.

\section{Countries invested in Bangladesh}

Telecommunication subsector under the service sector got maximum FDI in Bangladesh. Beside this agro based industries, garment/dyeing and other chemical sector are the major FDI receiver sectors in Bangladesh (Table 3).

\begin{tabular}{|c|c|c|}
\hline $\begin{array}{c}\text { Fiscal Year } \\
\text { (July to June) }\end{array}$ & $\begin{array}{c}\text { Net Foreign Direct Investment } \\
\text { (in million USD) }\end{array}$ & $\begin{array}{c}\text { Growth rate of net FDI inflow } \\
\text { (Percentage) }\end{array}$ \\
\hline $2004-05$ & 800 & Base Year \\
\hline $2005-06$ & 675 & $-15.62 \%$ \\
\hline $2006-07$ & 793 & $17.48 \%$ \\
\hline $2007-08$ & 748 & $-5.67 \%$ \\
\hline $2008-09$ & 961 & $28.47 \%$ \\
\hline $2009-10$ & 913 & $-4.99 \%$ \\
\hline $2010-11$ & 1136 & $24.42 \%$ \\
\hline $2011-12$ & 1292 & $13.73 \%$ \\
\hline $2012-13$ & 1599 & $23.76 \%$ \\
\hline $2013-14$ & 1526 & $-4.56 \%$ \\
\hline
\end{tabular}

Source: Compiled from Fiscal Year [11].

Table 1: FDI inflow to Bangladesh.

\begin{tabular}{|c|c|c|c|c|}
\hline SI. & Sectors & $\begin{array}{l}\text { No. of } \\
\text { Units }\end{array}$ & $\begin{array}{c}\text { Investment } \\
\text { (in million USD) }\end{array}$ & $\begin{array}{l}\text { Employment } \\
\text { Opportunities }\end{array}$ \\
\hline 1. & Agro based & 59 & 154.29 & 24,434 \\
\hline 2. & Chemical & 65 & 1985.93 & 6,147 \\
\hline 3. & Engineering & 57 & 38.96 & 4,388 \\
\hline 4. & Food and Allied & 13 & 19.11 & 1,662 \\
\hline 5. & Glass and Ceramic & 3 & 8.18 & 328 \\
\hline 6. & $\begin{array}{l}\text { Printing, publishing and } \\
\text { packaging }\end{array}$ & 7 & 2.26 & 325 \\
\hline 7. & $\begin{array}{l}\text { Tannery and rubber } \\
\text { products }\end{array}$ & 4 & 4.01 & 602 \\
\hline 8. & Textiles & 115 & 221.25 & 84,578 \\
\hline 9. & Services & 91 & 4575.90 & 18,758 \\
\hline 10. & Miscellaneous & 7 & 2.83 & 735 \\
\hline & Total & 418 & $7,012.67$ & 141,957 \\
\hline
\end{tabular}

Source: Investment Implementation Monitoring Cell (IIMC), Board of Investment. Table 2: Sector received maximum FDI (till 2010). 
Citation: Abdin MJ (2015) Foreign Direct Investment (FDI) in Bangladesh: Trends, Challenges and Recommendations. Int J Econ Manag Sci 4: 276. doi:10.4172/21626359.1000276

Page 4 of 5

\begin{tabular}{|c|c|c|c|}
\hline SI. & Country & No. of Units & $\begin{array}{c}\text { Investment } \\
\text { (in million UDS) }\end{array}$ \\
\hline 1. & United Arab Emirates & 6 & $2,229.89$ \\
\hline 2. & Kingdom of Saudi Arabia (KSA) & 4 & $1,850.40$ \\
\hline 3. & United Kingdom & 45 & 982.03 \\
\hline 4. & United States & 23 & 735.37 \\
\hline 5. & The Netherlands & 7 & 351.19 \\
\hline 6. & Egypt & 2 & 177.14 \\
\hline 7. & Malaysia & 7 & 162.00 \\
\hline 8. & South Korea & 43 & 123.70 \\
\hline 9. & India & 54 & 93.80 \\
\hline 10. & China & & 55.62 \\
\hline
\end{tabular}

Source: Alam [13].

Table 3: Top ten FDI investor countries in Bangladesh.

\begin{tabular}{|c|c|c|}
\hline FDI Component & $\begin{array}{c}\text { Amount } \\
\text { (in million USD) }\end{array}$ & Percentage \\
\hline Equity Capital & 270.59 & $18.08 \%$ \\
\hline Reinvested Earnings & 795.81 & $53.21 \%$ \\
\hline Extra company Loans & 429.10 & $28.69 \%$ \\
\hline Total FDI & $\mathbf{1 4 9 5 . 5}$ & $\mathbf{1 0 0} \%$ \\
\hline
\end{tabular}

Source: Foreign Direct Investment (FDI) [5].

Table 4: Component wise Percentage in FDI investment [14]

\section{Component wise share of FDI in Bangladesh}

During last few years Reinvested Earning is leading the FDI components. During July 2013 to June 2014 composition of FDI investment is as shown in Table 4. From Figure 1 it is quite clear that, the fresh FDI flow into Bangladesh is quit an insignificant amount in recent years. Reinvested capital is hiking the figure of FDI in Bangladesh.

\section{Major challenges to attract FDI into Bangladesh}

From the focused group discussion (FGD) and KII following challenges comes up to attract FDI into Bangladesh:

1. Limited capacity to supply adequate electricity and gas to industries.

2. Absence of efficient physical infrastructure.

3. Bureaucratic complexity to get registered or permission.

4. Absence of investment promoting agency.

5. Lack of professionals and sector specific trained man power

6. Poor imposition of IP (Intellectual Property) law.

7. Lack of project specific proposals in hand to attract international investment.

8. Non-cooperation from relevant government agencies like, the Board of Investment, Police, National Board of Revenue, Environment Authority etc.

9. Political unrest and blockades.

10. Absence of standardization/quality infrastructure in home.

11. Absence of technology infrastructure.

12. Corruption.
13. Differential treatment with the change of government.

14. Lack of administrative coordination among different government bodies.

15. Delay to get services from support organizations.

\section{Recommendations to increase FDI inflow in Bangladesh}

1. Increasing power generation and other utilities (like gas, water) supplies to the manufacturing entity.

2. Preparing complete project profile (PP) and approaching relevant multinational companies (MNCs).

3. Establishing an Investment Promotion Agency other than the Board of Investment (Regulator).

4. Increasing government's investment (could be under PPP modality) to achieve trust of foreign investors.

5. Functional one stop investment service center to reduce investment relevant harassments.

6. Increase/attract investment in infrastructure development.

7. Emphasizing on the job training to facilitate technology transfer and employment generation.

8. Attracting FDI into backward and forward linkage industries including testing laboratories, common facility centers, industrial park development and international value chain linkage industries.

9. Attracting cluster based investment to upgrade existing 177 SME Clusters in Bangladesh.

10. Emphasizing on labor intensive, import substitute, and export oriented industries.

\section{Conclusion}

Declaring a long range of fiscal/nonmonetary incentive or having competitive advantage in factors of production is not enough to get

\section{COMPONENT WISE SHARE OF FDI IN BANGLADESH (JULY 2013 - JUNE 2014}

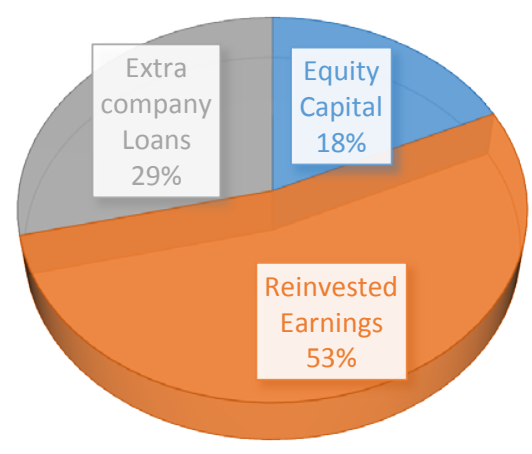

Source: Foreign Direct Investment (FDI) [5].

Figure 1: Component wise share of FDI. 
Citation: Abdin MJ (2015) Foreign Direct Investment (FDI) in Bangladesh: Trends, Challenges and Recommendations. Int J Econ Manag Sci 4: 276. doi:10.4172/21626359.1000276

Page 5 of 5

FDI into a country. Government has to be proactive for creating and maintaining an FDI friendly business environment in Bangladesh. To get satisfactory amount of FDI, Bangladesh has to complete its home work like identifying potential sectors, preparing specific project proposal, approaching potential FD Investor companies etc. Dedicated agency is needed to promote investment instead of regulator of investment. Ensuring hassle free power and utilities supply, smooth registration and certification mechanism has a direct linkage to get foreign or inspire local investment. Maintaining peaceful political and reliable legal environment is equally important to get foreign investment in a country. Bangladesh has to increase the amount of FDI attraction at any cost. Otherwise, it would be tough to achieve and maintain a double digit GDP growth. Without achieving doubledigit growth rate we cannot meet vision 2021 in time. Currently the figure of FDI investment is manipulated with reinvestment of locally earned profit. If we drop the locally earned profit amount as FDI then the figure during last few years is very dissatisfactory. So this is the pick time to concentrate upon it and start new drives for increasing FDI inflow into Bangladesh.

\section{References}

1. Lawson S, Heacock D, Stupnytska A (2007) Beyond the BRICS: A Look the 'Next 11'. Goldman Sachs investment bank.

2. Lisa Daniels National Private Sector Survey of Enterprises International Consulting Group and MIDAS.
3. Abdin MJ (2014) Cluster Development for Inclusive and Sustainable Economic Growth, Professionals Center for Business Research 1.

4. Foreign Direct Investment in Bangladesh 1971-2010 (2010) The Board of Investment, Government of Bangladesh.

5. Foreign Direct Investment (FDI) in Bangladesh, Survey Report (2014) Statistics Department, Bangladesh Bank.

6. World Investment Report (2014) United Nations Conference on Trade and Development (UNCTAD).

7. The Household Expenditure Survey (2010) Bangladesh Bureau of Statistics, Bangladesh.

8. Labor Force Survey (2010) Bangladesh Bureau of Statistics, Bangladesh.

9. Begum AA, Abdin MJ (2015) Employment Generation and Poverty Alleviation through SME Cluster Development in Bangladesh, Turkish Economic Review 2: 26-31.

10. Foreign Direct Investment (FDI) in Bangladesh (2013) Statistics Department, Bangladesh Bank (The Central Bank of Bangladesh).

11. Compiled from Fiscal Year 2004-05 to 2009-10 from "Bangladesh Economic Review 2012", Ministry of Finance, and Government of Bangladesh. Fiscal Year 2010-11 to 2013-14 from "Time Series Data on FDI Inflow" Foreign Investment and External Debt (FIED) Division, Statistics Department, Bangladesh Bank.

12. Investment Implementation Monitoring Cell (IIMC) Board of Investment, Government of Bangladesh.

13. Alam MS (2012) Foreign Direct Investment in Bangladesh: A Critical Analysis, South East Asian Journal of Contemporary Business, Economics and Law 1. 